\title{
ANALISA PENGARUH PENGEMBANGAN KARIR DAN MOTIVASI EKSTRINSIK, MOTIVASI INTRINSIK TERHADAP KINERJA SDM DENGAN KEPUASAN KERJA SEBAGAI VARIABEL INTERVENING
}

\author{
Ahmad Munif; Tatiek Nurhayati; Hardani Widhiastuti \\ muniflaksa@gmail.com.
}

Magister Manajemen, Universitas Semarang, Semarang, Indonesia

\begin{abstract}
Info Artikel Abstrak
Sejarah Artikel:

Diterima

Disetujui

Dipublikasikan

Keywords:

career

development;moti

vation; job

satisfaction;

Penelitian ini bertujuan untuk mengetahui pengaruh pengembangan karir, motivasi ektrinsik, dan motivasi intrinsik terhadap kinerja SDM dengan kepuasan kerja sebagai variabel intervening.

Responden yang digunakan adalah 60 karyawan pada Kantor Jasa Penilai Publik "Nirboyo Adiputro, Dewi Apriyanti \& Rekan. Data penelitian dikumpulkan dengan menggunakan kuesioner. Analisis data dilakukan dengan menggunakan Teknik Analisis Regresi Berganda, uji-t, dan analisis jalur.

Berdasarkan hasil penelitian diketahui bahwa (1) Pengembangan karir mempengaruhi kepuasan kerja karyawan KJPP NDR (2) Motivasi ektrinsik mempengaruhi kepuasan kerja karyawan KJPP NDR (3) Motivasi intrinsik mempengaruhi kepuasan kerja karyawan KJPP NDR (4) pengembangan karir mempengaruhi kinerja karyawan KJPP NDR (5) motivasi eksrinsik mempengaruhi kinerja karyawan KJPP NDR (6) motivasi intrinsik mempengaruhi kinerja karyawan KJPP NDR (7) kepuasan kerja mempengaruhi kinerja karyawan KJPP NDR.
\end{abstract}

performance

\section{ANALYSIS OF CAREER DEVELOPMENT AND MOTIVATION EXTRINSIC, INTRINSIC MOTIVATION TO PERFORMANCE WITH JOB SATISFACTION AS AN INTERVENING VARIABLE}

\begin{abstract}
This study aims to determine the effect of career development, motivation extrinsic and intrinsic motivation on the performance and job satisfaction as an intervening variable.

The respondents used were 60 employees at the Public Appraisal Services Office "Nirboyo Adiputro, Dewi Apriyanti \& Partners. Research data was collected using a questionnaire. Data analysis was performed using Multiple Regression Analysis Techniques, t-test, and path analysis.

Based on the results of the study it is known that (1) Career development affects the job satisfaction of KJPP NDR employees (2) Extrinsic motivation influences job satisfaction of KJPP NDR employees (3) Intrinsic motivation affects KJPP NDR employee job satisfaction (4) career development affects the performance of KJPP NDR employees (5) extrinsic motivation affects the performance of KJPP NDR employees (6) intrinsic motivation affects the performance of KJPP NDR employees (7) job satisfaction affects the performance of KJPP NDR employees .
\end{abstract}

\footnotetext{
\Alamat korespondensi :Jl. Soekarno-Hatta,Semarang

E-mail: muniflaksa@gmail.com·
} 


\section{PENDAHULUAN}

Kantor Jasa Penilai Publik Nirboyo Adiputro, Dewi Apriyanti \& Rekan (selanjutnya disingkat KJPP NDR) adalah transformasi dari PT. Laksa Laksana yang telah bergerak di bidang penilaian profesional di Indonesia sejak tahun 1989. Tranformasi ini sejalan dengan diterbitkannya Peraturan Menteri Keuangan Republik Indonesia No. 125 tertanggal 3 September 2008 yang mengatur peralihan bentuk usaha jasa penilai dari Perseroan Terbatas (PT) menjadi Kantor Jasa Penilai Publik (KJPP). Perubahan ini tertuang dalam Akta Notaris No. 132 tertanggal 28 Juni 2005 oleh Notaris Publik Ny. Hari Suprapti Suwarno, SH dan Akta Perubahan No. 13 tertanggal 16 Maret 2009 oleh Notaris Publik Hari Suprapti Suwarno, SH. KJPP Nirboyo Adiputro, Dewi Apriyanti \& Rekan (KJPP NDR) telah terdaftar pada Departemen Keuangan Republik Indonesia dengan Nomor Izin 2.09.0018.

Persaingan global di bidang jasa penilaian yang semakin intensif mencetuskan suatu ide perubahan mengimplikasikan bahwa praktek dan manajemen sumber daya manusia dapat memainkan suatu peran penting dalam mendorong kesetiaan karyawan dan membuat perusahaan mampu menghadapi perubahan-perubahan secara lebih baik. Manajemen sumber daya manusia harus dipandang sebagai perluasan dari pandangan tradisional untuk mengelola orang secara efektif dan untuk itu membutuhkan pengetahuan tentang manusia dan kemampuan mengelolanya. Sebagaimana dijelaskan oleh Mangkunegara (2013) bahwa manajemen sumber daya manusia adalah sebagai suatu pengelolaan dan pendayagunaan sumber daya yang ada pada individu. MSDM juga dapat merupakan kegiatan perencanaan, pengadaan, pengembangan, pemeliharaan, serta penggunaan SDM (selanjutnya disingkat SDM) untuk mencapai tujuan, baik secara individual maupun organisasi. Sumber daya manusia yang berkualitas merupakan competitive advantage dari suatu perusahaan. Oleh karena itu, pengelolaan SDM oleh manajemen mendapatkan perioritas utama. Melalui pengembangan SDM, diketahui kebutuhan SDM dan analisis yang merinci orang dengan kualifikasi tertentu. Melalui pengembangan SDM dari KJPP NDR, diharapkan KJPP NDR dapat bersaing dengan KJPP lainnya.

Prinsip utama layanan KJPP NDR adalah kepuasan konsumen atas jasa KJPP NDR sebagai penilai yang independen. Tujuan utama KJPP NDR adalah memberikan pelayanan yang sesuai dengan kompetensi KJPP NDR dengan kualitas terbaik dan objektif bagi kepentingan klien. Tujuan untuk memberikan pelayanan yang terbaik bagi konsumen dapat tercapai apabila SDM dari KJPP NDR dapat menunjukkan kinerja yang optimal.

Torang (2013) menyatakan bahwa kinerja (performance) adalah kuantitas dan atau kualitas hasil kerja individu atau sekelompok di dalam organisasi dalam melaksanakan tugas pokok dan fungsi yang berpedoman pada norma, standar operasional prosedur, kriteria dan ukuran yang telah ditetapkan atau yang berlaku dalam organisasi. Individu yang memiliki kinerja baik akan menunjukkan kuantitas dan kualitas dalam melaksanakan tugasnya sesuai dengan tanggung jawab yang diberikan kepadanya (Mangkunegara, 2007). Karyawan KJPP NDR diharapkan dapat menunjukkan kinerja yang maksimal, sehingga tujuan utama dari organisasi dapat tercapai.

Keberhasilan suatu organisasi sangat dipengaruhi oleh kinerja karyawannya. Setiap organisasi maupun perusahaan akan selalu berusaha untuk meningkatkan kinerja karyawannya, dengan harapan apa yang menjadi tujuan perusahaan akan tercapai. Salah satu cara yang ditempuh oleh perusahaan dalam meningkatkan kinerja karyawannya, 
misalnya dengan melalui pendidikan, pelatihan, pemberian kompensasi yang layak, pemberian motivasi, dan menciptakan lingkungan kerja yang kondusif (dalam Bambang Guritni dan Waridin, 2005).

Sukses tidaknya seorang karyawan dalam bekerja akan dapat diketahui apabila perusahaan atau organisasi yang bersangkutan menerapkan sistem penilaian kinerja. Kinerja adalah hasil kerja yang dapat dicapai oleh seseorang atau sekelompok orang dalam suatu organisasi, sesuai dengan wewenang dan tanggung jawab masing-masing dalam rangka upaya mencapai tujuan organisasi yang bersangkutan secara legal, tidak melanggar hukum dan sesuai dengan moral maupun etika. Pentingnya kinerja karyawan KJPP NDR seharusnya menjadi perhatian tersendiri bagi KJPP NDR agar pelayanan yang diberikan dapat maksimal. Namun demikian, di dalam menjalankan usahannya masih terlihat adanya kinerja pegawai KJPP NDR yang kurang dan masih ada kompline terhadap pelayanan jasa tersebut dari pemberi tugas.

Hasil penyebaran kuesioner tersebut sejalan dengan hasil studi dokumen yang dilakukan peneliti pada KJPP NDR terkait dengan masih belum optimalnya kinerja karyawan. Berdasarkan studi dokumen pada KJPP NDR, dapat diketahui adanya kegagalan dalam pencapaian target omzet dari tahun 2015 hingga tahun 2017. Data tersebut dapat dilihat pada tabel 1 di bawah ini.

Tabel 1

Penerimaan Pendapatan pada Tahun 2015-2017

\begin{tabular}{|l|c|c|c|c|c|c|}
\hline \multirow{2}{*}{ Tahun / } & \multicolumn{2}{|c|}{2015} & \multicolumn{2}{c|}{ 2016 } & \multicolumn{2}{c|}{ 2017 } \\
\cline { 2 - 7 } Dimensi & Target & Capaian & Target & Capaian & Target & Capaian \\
\hline Retail & Rp.4,8 & Rp.3,3 & Rp.5,5 & Rp.3,3 & Rp.5,5 & Rp.3,5 \\
& Milyar & Milyar & Milyar & Milyar & Milyar & Milyar \\
\hline Komersil & Rp.25 & Rp.21 & Rp.35 & Rp.34,8 & Rp.35 & Rp.21,2 \\
& Milyar & Milyar & Milyar & Milyar & Milyar & Milyar \\
\hline
\end{tabular}

Sumber: KJPP NDR, 2017

Berdasarkan tabel 1.2 di atas dapat diketahui adanya permasalahan kinerja SDM yang ditandai dengan kegagalan dalam pencapaian target omzet pada KJPP NDR. Kegagalan pencapaian target tersebut dapat berdampak pada kelangsungan roda organisasi di masa depan.

Mangkunegara (2013) menyatakan bahwa kinerja dipengaruhi oleh beberapa faktor, salah satunya adalah dukungan organisasi. Salah satu bentuk dukungan yang dberikan oleh organisasi terhadap karyawan adalah adanya pengembangan karir bagi karyawan. Kemajuan karir seringkali menjadi obsesi banyak karyawan, dan seringkali menjadi pikiran karyawan daripada pihak manajemen perusahaan (Ruky, dalam Sutrisno, 2009). Pengembangan karir sebenarnya juga menjadi tanggung jawab kedua belah pihak, baik karyawan maupun pihak manajemen perusahaan. Karyawan yang mempunyai visi dan ambisi untuk mengembangkan karir harus selalu mengambil inisiatif dan tindakan yang akan membantu mengembangkan karirnya.

Mangkunegara (2007), berpendapat bahwa pengembangan karir adalah aktivitas kepegawaian yang membantu pegawai-pegawai merencanakan karir masa depan mereka di perusahaan agar perusahaan dan pegawai yang bersangkutan dapat mengembangkan diri secara maksimum. Pengembangan karir juga dapat didefinisikan sebagai semua usaha pribadi karyawan yang ditujukan untuk melaksanakan rencana karirnya melalui 
pendidikan, pelatihan, pencarian dan perolehan kerja, serta pengalaman kerja (Panggabean, 2002).

Pengembangan karir akan menciptakan beneficial mutualis, yakni suatu kondisi dimana karyawan dan perusahaan sama-sama memetik manfaat dan terus dapat berkembangnya segenap potensi diri karyawan yang selaras dengan berkembangnya organisasi (Sutrisno, 2009). Pengembangan karir yang diselenggarakan oleh KJPP NDR merupakan langkah yang seharusnya dapat menunjang pencapaian kinerja dari karyawan. Sebagaimana hasil penelitian yang dilakukan oleh Baroroh (2016) yang menunjukkan bahwa pengembangan karir berpengaruh positif terhadap kepuasan kerja dan kinerja.

Pengembangan karir juga memiliki peran penting bagi peningkatan kepuasan kerja karyawan KJPP NDR. Memberikan kepuasan kerja bagi karyawan adalah kewajiban setiap pemimpin perusahaan, karena kepuasan kerja merupakan faktor yang diyakini dapat mendorong dan mempengaruhi semangat kerja karyawan agar karyawan dapat bekerja dengan baik dan secara langsung akan mempengaruhi prestasi kerja. Penelitian terdahulu yang dilakukan oleh Ningsih (2012) menunjukkan bahwa ada hubungan positif yang sangat signifikan antara pengembangan karir dengan kepuasan kerja, artinya peningkatan pada pengembangan karir maka akan disertai dengan peningkatan kepuasan kerja. Terciptanya kepuasan kerja akibat pengembangan karir yang jelas, dapat semakin meningkatkan pencapaian kinerja karyawan KJPP NDR.

Torang (2013) mengemukakan bahwa terdapat beberapa faktor yang memengaruhi kinerja, salah satunya adalah faktor individu, yaitu motivasi. Robert dan Heller (dalam Wibowo, 2013) menyatakan bahwa motivasi adalah keinginan untuk bertindak. Setiap orang dapat termotivasi oleh beberapa kekuatan yang berbeda. Motivasi kerja akan diarahkan pada pencapaian tujuan organisasi. Individu yang memiliki motivasi akan dapat menunjukkan usaha yang berkaitan dengan pekerjaan dan mempertimbangkan arah, intensitas dan ketekunannya. Motivasi yang dimiliki oleh karyawan akan menjadikan karyawan semakin terpacu untuk dapat bekerja sesuai dengan acuan kerja dan tanggung jawab yang diberikan dengan baik. Kuat lemahnya motivasi yang dimiliki karyawan KJPP NDR, baik motivasi intrinsik ataupun motivasi ekstrinsik sangat menentukan wujud atau pencapaian kinerjanya. Tercapainya kinerja optimal akibat adanya motivasi yang dimiliki karyawan disebabkan dengan adanya motivasi, karyawan akan terpuaskan sehingga karyawan akan bersedia menunjukkan kinerja yang optimal. Sebagaimana penelitian terdahulu yang dilakukan oleh Putra dan Frianto (2013) yang menunjukkan bahwa motivasi intrinsik dan motivasi ekstrinsik secara simultan berpengaruh kuat terhadap kepuasan kerja pegawai Departemen Sumber Daya Manusia di PT. Semen Gresik (Persero) Tbk. Hasil penelitian tersebut ditunjang oleh penelitian yang dilakukan Muslih (2012) bahwa kepuasan kerja berpengaruh signifikan terhadap kinerja pegawai.

Meskipun telah banyak penelitian terdahulu yang menunjukkan pengaruh pengembangan karir dan motivasi ektrinsik, motivasi intrinsik terhadap kinerja SDM dengan kepuasan kerja, akan tetapi masih terdapat gap diantara penelitian terdahulu. Berikut ini disajikan riset gap yang mendasari dilakukannya penelitian. 
Tabel 2

Riset Gap

\begin{tabular}{|c|l|l|}
\hline ISSUE GAP & \multicolumn{1}{|c|}{$\begin{array}{c}\text { Peneliti } \\
\text { dan Tahun }\end{array}$} & Hasil Penelitian \\
\hline $\begin{array}{c}\text { Pengaruh } \\
\text { pengembangan } \\
\text { karir terhadap } \\
\text { kinerja }\end{array}$ & $\begin{array}{l}\text { Ita Rifiani Permatasari (2006) } \\
\text { Tenaldy Massie, Bernhard }\end{array}$ & Berpengaruh positif \\
\hline $\begin{array}{c}\text { Pengaruh motivasi } \\
\text { terhadap kinerja }\end{array}$ & $\begin{array}{l}\text { Wawan Sendow (2015) } \\
\text { Nopiyana Simbolon (2014) }\end{array}$ & \\
\cline { 2 - 3 } & Basthoumi Muslih (2012) & Tidak berpengaruh \\
\hline $\begin{array}{c}\text { Pengaruh Motivasi } \\
\text { kerja terhadap } \\
\text { Kinerja melalui } \\
\text { Kepuasan Kerja }\end{array}$ & $\begin{array}{l}\text { Lidia Lusri dan Hotlan Siagian } \\
\text { (2017) }\end{array}$ & Memediasi \\
\cline { 2 - 3 } & $\begin{array}{l}\text { Vivi Amanah Harahap dan } \\
\text { Wahyu Hidayat (2017) }\end{array}$ & Tidak mediasi \\
\hline
\end{tabular}

Berbagai latar belakang yang menunjukkan permasalahan turunnya kinerja dan terdapat riset gap yang menunjukkan bahwa kepuasan kerja tidak memediasi pengaruh motivasi terhadap kinerja karyawan, maka terdapat beberapa persoalan penelitian sebagai berikut:

1. Apakah pengembangan karir berpengaruh terhadap kepuasan kerja karyawan KJPP NDR?

2. Apakah motivasi ektrinsik berpengaruh terhadap kepuasan kerja karyawan KJPP NDR?

3. Apakah motivasi intrinsik berpengaruh terhadap kepuasan kerja karyawan KJPP NDR?

4. Apakah pengembangan karir berpengaruh terhadap kinerja karyawan KJPP NDR?

5. Apakah motivasi ektrinsik berpengaruh terhadap kinerja karyawan KJPP NDR?

6. Apakah motivasi intrinsik berpengaruh terhadap kinerja karyawan KJPP NDR dengan mediasi variabel kepuasan kerja?

7. Apakah kepuasan kerja berpengaruh terhadap kinerja karyawan KJPP NDR?

\section{TELAAH PUSTAKA}

\section{Hubungan antara Pengembangan Karir dengan Kepuasan Kerja Karyawan KJPP NDR}

Dalam suatu organisasi tentu terdapat suatu tujuan yang ingin dicapai. Salah satu faktor yang mendukung dalam pencapaian tujuan adalah kepuasan kerja. Untuk mewujudkan tujuan tersebut diperlukan sumber daya manusia yang handal dan berdedikasi. Hal tersebut dipengaruhi oleh kepuasan kerja. Kepuasan kerja merupakan salah satu faktor yang sangat penting untuk mendapatkan hasil kerja yang optimal. Menurut Fleisman dan Bass (dalam Wijono, 2012) kepuasan kerja merupakan suatu tindakan efektif karyawan terhadap pekerjaannya. Kepuasan kerja dianggap sebagai hasil pengalaman karyawan dalam kaitannya dengan penilaian terhadap diri sendiri seperti apa yang dikehendaki atau diharapkan dari pekerjaannya. Ketika seorang merasakan kepuasan dalam bekerja tentunya ia akan berupaya semaksimal mungkin dengan segenap kemampuan yang dimilikinya untuk menyelesaikan tugas 
pekerjaannya. Dengan demikian produktivitas dan hasil kerja pegawai akan meningkat secara optimal, secara otomatis sumber daya manusia akan meningkat dan akan merasakan adanya kepuasan kerja dengan sendirinya.

Lisdiani (2017) dalam penelitiannya menyimpulkan bahwa pengembangan karir berpengaruh signifikan terhadap kepuasan kerja pada Hotel Grasia Semarang. Begitu juga halnya dengan penelitian terdahulu yang dilakukan oleh Ambarwati, dkk (2016) yang menunjukkan bahwa pengembangan karir yang terdiri dari persamaan karir, masalah pengawasan, kesediaan akan kesempatan dan minat karyawan berpengaruh signifikan terhadap kepuasan kerja karyawan di PT. Kusuma Satria Dinasasri Wisatajaya. Mengacu pada uraian di atas maka dapat dirumuskan hipotesis sebagai berikut:

H1 = Pengembangan karir berpengaruh positif terhadap kepuasan kerja karyawan KJPP NDR

\section{Hubungan antara Motivasi Ektrinsik dengan Kepuasan Kerja Karyawan KJPP NDR}

Persaingan global di dunia bisnis semakin ketat ditandai dengan perubahan lingkungan yang cepat, sehingga menuntut kepekaan organisasi dalam merespon perubahan yang akan terjadi dalam kancah persaingan global. Pada masa yang akan datang, harus disadari bahwa sumber daya manusia akan membutuhkan suatu model dan proses untuk memperoleh kecakapan dalam dunia global, keefektifan dalam bekerja dan kemampuan dalam berkompetisi. Sumber daya manusia merupakan salah satu unsur yang sangat menentukan keberhasilan suatu organisasi mencapai tujuan.

Untuk mencapai tujuan organisasi maka hal yang perlu dilakukan adalah memberi daya pendorong yang mengakibatkan, menyalurkan dan memelihara perilaku pegawai agar bersedia bekerja sesuai dengan yang diinginkan organisasi. Daya pendorong tersebut disebut sebagai motivasi. Motivasi adalah dorongan terhadap serangkaian proses perilaku manusia pada pencapaian tujuan (Wibowo, 2011). Salah satu jenis rangsangan motivasi tersebut, yaitu motivasi ekstrinsik.

Hal ini didukung dengan teori Herzberg (1960) dalam Tampubolon (2004) yang mengemukakan bahwa ada serangkaian kondisi ekstrinsik, di mana keadaan pekerjaan dan hygieni yang menyebabkan rasa tidak puas di antara para karyawan apabila kondisi ini tidak ada, maka hal ini tidak perlu memotivasi karyawan. Sebaliknya, apabila keadaan pekerjaan dan hygieni cukup baik, keadaan ini dapat membentuk kepuasan bagi karyawan. Sebagaimana hasil penelitian terdahulu yang dilakukan oleh Putra dan Frianto (2016) yang menunjukkan bahwa motivasi ekstrinsik mempunyai pengaruh positif terhadap kepuasan kerja Departemen Sumber Daya Manusia di PT. Semen Gresik (Persero) Tbk. Mengacu pada uraian tersebut maka dapat dirumuskan hipotesis sebagai berikut:

$\mathrm{H} 2$ = Motivasi ektrinsik berpengaruh positif terhadap kepuasan kerja karyawan KJPP NDR

\section{Hubungan antara Motivasi Intrinsik dengan Kepuasan Kerja Karyawan KJPP NDR}

Herzberg berpendapat bahwa apabila para manajer ingin memberikan motivasi pada bawahannya, yang perlu ditekankan adalah faktor-faktor yang menimbulkan rasa puas, yaitu dengan mengutamakan faktor-faktor motivasional yang bersifat internal (Noermijati, 2010). Juga seperti yang ditemukan oleh Octaviana (2011), Purnomowati 
(2006), Brahmasari dan Suprayetno (2008) bahwa motivasi sangat memengaruhi kepuasan kerja dan Noermijati (2008) yang mengemukakan bahwa faktor intrinsik/motivator memengaruhi kepuasan manajer operasional. Motivasi intrinsik melibatkan orang yang melakukan suatu kegiatan karena merasa menarik dan memperoleh kepuasan langsung dari kegiatan itu sendiri. Motivasi ekstrinsik membutuhkan perantara antara aktivitas dan beberapa konsekuensi yang dipisahkan seperti penghargaan nyata, sehingga kepuasan berasal dari konsekuensi ekstrinsik yang menuntun kegiatan.

Penelitian yang dilakukan oleh Muslih (2012) menunjukkan bahwa motivasi intrinsik berpengaruh signifikan terhadap kepuasan kerja. Koefisien yang positif mengindikasikan bahwa motivasi intrinsik memberikan pengaruh yang positif terhadap kepuasan kerja. Yang berarti semakin tinggi motivasi intrinsik pegawai, maka kepuasan kerja pegawai akan semakin tinggi pula. Sebaliknya, semakin rendah motivasi intrinsik pegawai, maka kepuasan kerja juga akan semakin rendah. Mengacu pada uraian tersebut maka dapat dirumuskan hipotesis sebagai berikut:

$\mathrm{H} 3$ = Motivasi intrinsik berpengaruh positif terhadap kepuasan kerja karyawan KJPP NDR

\section{Hubungan antara Pengembangan Karir dengan Kinerja Karyawan KJPP NDR}

Pentingnya peranan Sumber Daya Manusia dalam suatu perusahaan agar dapat dimanfaatkan seefektif mungkin, maka diperlukan cara-cara untuk menggerakkan agar manusia atau para karyawan mau bekerja dan menggunakan skill atau kemampuan yang dimilikinya secara maksimal. Salah satu cara yaitu dengan cara pengembangan karir yang jelas. Mangkunegara (2007), berpendapat bahwa pengembangan karir adalah aktivitas kepegawaian yang membantu pegawai-pegawai merencanakan karir masa depan mereka di perusahaan agar perusahaan dan pegawai yang bersangkutan dapat mengembangkan diri secara maksimum. Pengembangan karir juga dapat didefinisikan sebagai semua usaha pribadi karyawan yang ditujukan untuk melaksanakan rencana karirnya melalui pendidikan, pelatihan, pencarian dan perolehan kerja, serta pengalaman kerja (Panggabean, 2002). Pengembangan karir yang diselenggarakan oleh suatu perusahaan dapat meningkatkan kesediaan karyawan KJPP NDR untuk menunjukkan kinerja yang optimal.

Penelitian terdahulu yang dilakukan oleh Permatasari (2006) menunjukkan bahwa pengembangan karir karyawan yang ditunjukkan dengan variabel perencanaan karir dan manajemen karir yang baik akan memacu kinerja karyawan. Dewi dan Utama (2016) menyimpulkan hasil penelitiannya bahwa pengembangan karir berpengaruh positif dan signifikan terhadap kinerja karyawan. Hal ini menunjukkan semakin baik pengembangan karir karyawan maka semakin meningkat pula kinerja karyawan. Mengacu pada uraian tersebut maka dapat dirumuskan hipotesis sebagai berikut: H4 = Pengembangan karir berpengaruh positif terhadap kinerja karyawan KJPP NDR

\section{Hubungan antara Motivasi Ektrinsik dengan Kinerja Karyawan KJPP NDR}

Kinerja adalah hasil kerja yang dicapai oleh seseorang atau sekelompok orang dalam suatu organisasi, sesuai dengan wewenang dan tanggung jawab masing-masing, dalam rangka upaya mencapai tujuan organisasi bersangkutan secara legal, tidak melanggar hukum dan sesuai dengan moral atau etika. Bekerja sebagai pegawai dituntut untuk dapat menunjukkan kinerja yang maksimal karena pegawai harus senantiasa 
memberikan pelayanan kepada masyarakat. Mangkunegara (2007) menyatakan bahwa faktor-faktor yang memengaruhi pencapaian kinerja, salah satunya adalah motivasi.

Motivasi ekstrinsik timbul sebagai akibat pengaruh dari luar individu, apakah karena adanya ajakan, suruhan, atau paksaan dari orang lain sehingga dengan keadaan demikian seseorang mau melakukan sesuatu tindakan contohnya belajar (Suwatno dan Priansa, 2011). Hasil penelitian yang dilakukan Purwati (2012) menunjukkan bahwa motivasi kerja berpengaruh terhadap kinerja karyawan. Motivasi kerja merupakan kondisi atau energi yang menggerakkan diri karyawan yang terarah atau tertuju untuk mencapai tujuan organisasi perusahaan (Mangkunegara, 2007).

Karyawan yang memiliki motivasi kerja akan bersungguh-sungguh dalam bekerja dan berusaha agar setiap target yang ditetapkan oleh perusahaan tercapai. Begitu juga halnya dengan penelitian yang dilakukan oleh Muslih (2012) yang menunjukkan bahwa motivasi ekstrinsik berpengaruh signifikan terhadap kinerja pegawai. Koefisien yang positif mengindikasikan bahwa motivasi ekstrinsik memberikan pengaruh yang positif terhadap kinerja pegawai. Yang berarti semakin tinggi motivasi ekstrinsik pegawai, maka kinerja pegawai akan semakin tinggi pula. Sebaliknya, semakin rendah motivasi ekstrinsik pegawai, maka kinerja pegawai juga akan semakin rendah. Mengacu pada uraian tersebut maka dapat dirumuskan hipotesis sebagai berikut:

H5 = Motivasi ektrinsik berpengaruh positif terhadap kinerja karyawan KJPP NDR

\section{Hubungan antara Motivasi Intrinsik dengan Kinerja Karyawan di KJPP NDR}

Motivasi intrinsik adalah motivasi yang mendorong seseorang untuk berprestasi yang bersumber dalam diri individu tersebut, yang lebih dikenal dengan faktor motivasional. Menurut Herzberg Faktor motivator (intrinsik) memotivasi seseorang untuk berusaha mencapai kepuasan, yang termasuk di dalamnya adalah keberhasilan yang diraih, pengakuan atau penghargaan, pekerjaan itu sendiri, tanggung jawab, dan peluang untuk berkembang (faktor intrinsik).

Motivasi intrinsik merupakan hal yang sangat penting bagi kehidupan suatu organisasi terutama peningkatan kinerja secara optimal. Sejalan dengan yang ditemukan oleh Mahesa (2010), Purnomowati (2006), Widyastuti (2004), Octaviana (2011), dan Nugraheni (2003) bahwa motivasi ekstrinsik mempunyai pengaruh yang signifikan terhadap kinerja pegawai. Penelitian terdahulu yang dilakukan Prahiawan dan Simbolon (2014) menunjukkan bahwa motivasi intrinsik mempunyai pengaruh yang signifikan terhadap kinerja karyawan pada PT. Intimas Lestari Nusantara. Mengacu pada uraian tersebut maka dapat dirumuskan hipotesis sebagai berikut:

H6 = Motivasi intrinsik berpengaruh positif terhadap kinerja karyawan KJPP NDR

\section{Hubungan antara Kepuasan Kerja dengan Kinerja Karyawan di KJPP NDR}

Keberhasilan suatu organisasi sangat dipengaruhi oleh kinerja individu karyawannya. Setiap organisasi maupun perusahaan akan selalu berusaha untuk meningkatkan kinerja karyawan, dengan harapan apa yang menjadi tujuan perusahaan akan tercapai. Salah satu cara yang ditempuh oleh perusahaan dalam meningkatkan kinerja karyawannya, misalnya dengan melalui pendidikan, pelatihan, pemberian kompensasi yang layak, pemberian motivasi dan menciptakan lingkungan kerja yang kondusif (Guritno dan Waridin, 2005). Salah satu langkah penting yang dapat dilakukan oleh perusahaan guna mencapai kinerja yang optimal adalah meningkatkan kepuasan kerja karyawan. 
Penelitian terdahulu yang dilakukan oleh Mardiana, dkk (2014: 127) menunjukkan bahwa terdapat hubungan antara kepuasan kerja dengan turnover intention. Semakin tinggi tingkat kepuasan seseorang maka akan membuat orang tersebut semakin tidak ingin meninggalkan pekerjaan atau resign. Lebih lanjut penelitian Baroroh (2016) menunjukkan bahwa kepuasan kerja berpengaruh positif terhadap kinerja. Mengacu pada uraian tersebut maka dapat dirumuskan hipotesis sebagai berikut:

H7 = Kepuasan kerja berpengaruh positif terhadap kinerja karyawan KJPP NDR

\section{METODE}

Dalam penelitian ini peneliti menggunakan pendekatan penelitian kuantitatif. Data yang digunakan dalam penelitian ini adalah data primer, yaitu data diperoleh secara langsung dengan membagi kuesioner atau daftar pertanyaan kepada KJPP Jimmy Prasetyo \& Rekan, dan data sekunder yang diperoleh dari KJPP Jimmy Prasetyo \& Rekan. Peneliti menggunakan semua anggota populasi sebagai sampel yang berjumlah 60 orang. Teknik pengumpulan data dalam penelitian ini dengan kuesioner yang disusun dengan menurunkan beberapa aspek yang terkait dengan variabel penelitian. Teknik analisis data yang digunakan, meliputi uji validitas dan reliabilitas, analisis deskriptif, analisis regresi linier berganda, uji-t, analisis jalur, dan koefisien determinasi.

\section{HASIL DAN PEMBAHASAN}

\section{Deskripsi tentang Pengembangan Karir (X1)}

Berdasarkan analisis deskriptif yang mengacu pada three box method diketahui bahwa karyawan Kantor Jasa Penilai Publik "Nirboyo Adiputro, Dewi Apriyanti \& Rekan memiliki anggapan mengenai pengembangan karir dalam kategori sedang. Hal tersebut berarti bahwa karyawan cukup memiliki penilaian bahwa pekerjaan yang dilakukan sesuai dengan minat pribadinya. Pengembangan karir yang tergolong pada kategori sedang, seharusnya dapat lebih ditingkatkan karena dapat berpengaruh terhadap performa karyawan dalam bekerja.

\section{Deskripsi tentang Motivasi Ekstrinsik (X2)}

Berdasarkan analisis deskriptif yang mengacu pada three box method menunjukkan bahwa sebagian besar responden, yaitu karyawan Kantor Jasa Penilai Publik "Nirboyo Adiputro, Dewi Apriyanti \& Rekan memiliki motivasi ekstrinsik dalam kategori yang sedang. Motivasi ekstrinsik yang tergolong sedang berarti bahwa karyawan Kantor Jasa Penilai Publik "Nirboyo Adiputro, Dewi Apriyanti \& Rekan cukup terdorong untuk bekerja secara optimal dengan adanya dukungan dari perusahaan.

\section{Deskripsi tentang Motivasi intrinsik (X3)}

Berdasarkan analisis deskriptif yang mengacu pada three box method sebagian besar responden, yaitu karyawan Kantor Jasa Penilai Publik "Nirboyo Adiputro, Dewi Apriyanti \& Rekan memiliki motivasi intrinsik dalam kategori sedang. Pada variabel motivasi intrinsik, indikator tertinggi terletak pada indikator pertama, yaitu keberhasilan dalam menyelesaikan pekerjaan.Hal tersebut tidak terlepas dari adanya tuntutan perusahaan untuk memberikan penilaian yang terbaik dan sesuai dengan kondisi dari klien. Indikator terendah paling terletak pada indikator ketujuh, yaitu penghargaan atas 
prestasi dari perusahaan. Penghargaan pada dasarnya telah diberikan kepada karyawan, akan tetapi karyawan masih menganggap jumlah yang diterima masih kurang sesuai dengan harapannya.

\section{Deskripsi tentang Kepuasan Kerja (Y1)}

Berdasarkan analisis deskriptif yang mengacu pada three box method diketahui bahwa sebagian besar karyawan Kantor Jasa Penilai Publik "Nirboyo Adiputro, Dewi Apriyanti \& Rekan memiliki kepuasan kerja dalam kategori yang sedang. Perusahaan dianggap telah menyediakan kesempatan bagi karyawan untuk belajar kepada karyawan yang lebih berpengalaman, akan tetapi masih terdapat karyawan yang kurang memiliki inisiatif untuk mempelajarinya lebih lanjut.

\section{Deskripsi tentang Kinerja SDM (Y2)}

Berdasarkan analisis deskriptif yang mengacu pada three box method sebagian besar karyawan Kantor Jasa Penilai Publik "Nirboyo Adiputro, Dewi Apriyanti \& Rekan memiliki kinerja dalam kategori sedang. Hal tersebut berarti bahwa karyawan masih kurang menunjukkan daya upaya dalam pencapaian target pekerjaan.Kondisi tersebut tidak dapat dibiarkan berlangsung terus menerus karena dapat mengancam kelangsungan perusahaan di masa yang akan datang.

\section{Analisis Regresi Linier Berganda}

Analisis statistik yang digunakan dalam penelitian ini yaitu regresi linier berganda. Analisis ini digunakan untuk mengetahui besarnya pengaruh pengembangan karir, motivasi intrinsik, motivasi ekstrinsik, dan kepuasan kerja terhadap kinerja SDM. Berdasarkan perhitungan pengujian analisis regresi linier berganda dapat diperoleh hasil sebagai berikut :

\section{Tabel 3}

Hasil Analisis Regresi Berganda

\begin{tabular}{|c|r|r|r|r|r|}
\hline \multirow{2}{*}{ Model } & \multicolumn{2}{|c|}{$\begin{array}{c}\text { Unstandardized } \\
\text { Coefficients }\end{array}$} & $\begin{array}{c}\text { Standardized } \\
\text { Coefficients }\end{array}$ & \multirow{2}{*}{ Sig. } \\
\cline { 2 - 5 } & \multicolumn{1}{|c|}{$\mathrm{B}$} & Std. Error & \multicolumn{1}{c|}{ Beta } & & \\
\hline \multirow{2}{*}{ (Constant) } & $-4,510$ & 3,682 & & $-1,225$ &, 226 \\
Pengembangan Karir &, 287 &, 134 &, 228 & 2,139 &, 037 \\
1 Motivasi Ekstrinsik &, 216 &, 095 &, 214 & 2,275 &, 027 \\
Motivasi Intrinsik &, 406 &, 101 &, 398 & 4,039 &, 000 \\
Kepuasan Kerja &, 179 &, 086 &, 241 & 2,079 &, 042 \\
\hline
\end{tabular}

a. Dependent Variable: Kinerja SDM

Sumber : data primer yang diolah 2018

Berdasarkan tabet tersebut hasil uji t terlihat variabel pengembangan karir, motivasi ekstrinsik, motivasi intrinsik, dan kepuasan kerja berpengaruh positif terhadap kinerja SDM dengan signifikan <0,05. Dari tabel tersebut juga dapat dibuat persamaan matematis sebagai berikut:

$$
\hat{\mathrm{Y}}=0,228 \mathrm{X} 1+0,214 \mathrm{X} 2+0,398 \mathrm{X} 3+0,241 \mathrm{X} 4
$$


1. Nilai koefisien regresi dari variabel pengembangan karir sebesar 0,228 memiliki arah positif, dengan signifikansi sebesar 0,037 lebih kecil 0,05, sehingga pengembangan karir berpengaruh positif signifikan terhadap kinerja SDM, artinya semakin baik pengembagan karir akan meningkatkan kinerja SDM.

2. Nilai koefisien regresi dari variabel motivasi ekstrinsik sebesar 0,214 memiliki arah positif,dengan signifikansi sebesar 0,027 lebih kecil 0,05, sehingga motivasi ekstrinsik berpengaruh positif signifikan terhadap kinerja SDM, artinya semakin baik motivasi ekstrinsik akan meningkatkan kinerja SDM

3. Nilai koefisien regresi dari variabel motivasi intrinsik sebesar 0,398 memiliki arah positif,dengan signifikansi sebesar 0,000 lebih kecil 0,05, sehingga motivasi intrinsik berpengaruh positif signifikan terhadap kinerja SDM,artinya semakin baik motivasi intrinsik akan meningkatkan kinerja SDM.

4. Nilai koefisien regresi dari variabel kepuasan kerja sebesar 0,241 memiliki arah positif,dengan signifikansi sebesar 0,042 lebih kecil 0,05, sehingga kepuasan kerja berpengaruh positif signifikan terhadap kinerja SDM,artinya semakin baik kepuasan kerja akan meningkatkan kinerja SDM.

\section{Uji Hipotesis (Uji-t)}

Uji parsial atau uji t dilakukan untuk mengetahui pengaruh variabel independen (X) terhadap variabel dependen (Y). Jika probabilitas (dalam tabel ditandai dengan Sig (p) < 0,05, maka $\mathrm{H}_{0}$ ditolak dan sebaliknya jika probabilitas $>0,05$, maka $\mathrm{H}_{0}$ diterima artinya tidak ada pengaruh secara signifikan. Hasil analisis uji parsial (Uji t) dalam penelitian ini dapat dijelaskan sebagai berikut:

\section{Tabel 4}

Uji-t

\begin{tabular}{|c|c|c|c|c|c|c|c|c|}
\hline \multirow{2}{*}{ Variabel Independen } & \multicolumn{4}{|c|}{$\begin{array}{c}\text { Dependen Variabel Kepuasan } \\
\text { Kerja }\end{array}$} & \multicolumn{4}{|c|}{$\begin{array}{c}\text { Dependen Variabel Kinerja } \\
\text { SDM }\end{array}$} \\
\hline & $\begin{array}{c}\mathrm{t}- \\
\text { hitung }\end{array}$ & $\begin{array}{c}\text { t- } \\
\text { tabel }\end{array}$ & Sig. & Kriteria & $\begin{array}{c}\text { t- } \\
\text { hitung }\end{array}$ & $\begin{array}{c}\text { t- } \\
\text { tabel }\end{array}$ & Sig. & Kriteria \\
\hline Pengembangan Karir & 3,893 & 2,002 &, 000 & $\begin{array}{l}<0,05, \\
\text { Signifikan }\end{array}$ & 2,139 & 2,002 & ,037 & $\begin{array}{c}<0,05, \\
\text { Signifikan }\end{array}$ \\
\hline Motivasi Ekstrinsik & 2,161 & 2,002 & ,035 & $\begin{array}{c}<0,05, \\
\text { Signifikan }\end{array}$ & 2,275 & 2,002 & ,027 & $\begin{array}{c}<0,05 \\
\text { Signifikan }\end{array}$ \\
\hline Motivasi Intrinsik & 2,436 & 2,002 &, 018 & $\begin{array}{l}<0,05, \\
\text { Signifikan }\end{array}$ & 4,039 & 2,002 & ,000 & $\begin{array}{c}<0,05, \\
\text { Signifikan }\end{array}$ \\
\hline Kepuasan Kerja & & & & & 2,079 & 2,002 & ,042 & $\begin{array}{c}<0,05 \\
\text { Signifikan }\end{array}$ \\
\hline
\end{tabular}

Sumber : data primer yang diolah 2018

1. Pengujian Hipotesis $1(\mathrm{H} 1)$

Berdasarkan hasil pengujian hipotesis (uji t) variabel pengembangan karir diperoleh nilai t-hitung sebesar 3,893 dengan nilai signifikansi sebesar 0,000 (< $0,05)$. Tabel distibusi $\mathrm{t}$ dicari pada $\mathrm{a}=5 \%$ dengan derajat bebas $(\mathrm{df})=\mathrm{n}-\mathrm{k}-1=60-3-1$ $=56, \mathrm{n}$ adalah jumlah kasus (sampel), $\mathrm{k}$ adalah jumlah variabel independen).

Nilai t-hitung lebih besar dibandingkan nilai t-tabel $(3,893>2.00324)$ dan nilai signifikan lebih kecil dari 0,05 , sehingga dapat disimpulkan bahwa variabel 
pengembangan karir berpengaruh positif terhadap kepuasan kerja karyawan KJPP NDR atau H1 diterima, artinya semakin baik pengembangan karir akan meningkatkan kepuasan kerja.

2. Pengujian Hipotesis $2(\mathrm{H} 2)$

Berdasarkan hasil pengujian hipotesis (uji t) variabel motivasi ekstrinsik diperoleh nilai t-hitung sebesar 2,161 dengan nilai signifikansi sebesar 0,035 (< $0,05)$. Tabel distibusi t dicari pada $\mathrm{a}=5 \%$ dengan derajat bebas $(\mathrm{df})=\mathrm{n}-\mathrm{k}-1=60-3$ $1=56, \mathrm{n}$ adalah jumlah kasus (sampel), $\mathrm{k}$ adalah jumlah variabel independen.

Nilai t-hitung lebih besar dibandingkan nilai t-tabel $(2,161>2.00324)$ dan nilai signifikan lebih kecil dari 0,05, sehingga dapat disimpulkan bahwa variabel Motivasi ektrinsik berpengaruh positif terhadap kepuasan kerja karyawan KJPP NDR atau H2 diterima, artinya semakin baik motivasi ekstrinsik akan meningkatkan kepuasan kerja.

3. Pengujian Hipotesis $3(\mathrm{H} 3)$

Berdasarkan hasil pengujian hipotesis (uji t) variabel motivasi intrinsik diperoleh nilai t-hitung sebesar 2,436 dengan nilai signifikansi sebesar 0,018 (< $0,05)$. Tabel distibusi t dicari pada $\mathrm{a}=5 \%$, dengan derajat bebas $(\mathrm{df})=\mathrm{n}-\mathrm{k}-1=60-3$ $1=56, \mathrm{n}$ adalah jumlah kasus (sampel), $\mathrm{k}$ adalah jumlah variabel independen).

Nilai t-hitung lebih besar dibandingkan nilai t-tabel $(2,436>2.00324)$ dan nilai signifikan lebih kecil dari 0,05, sehingga dapat disimpulkan bahwa variabel motivasi intrinsik berpengaruh positif terhadap kepuasan kerja karyawan KJPP NDR atau H3 diterima,artinya semakin baik motivasi intrinsik akan meningkatkan kepuasan kerja.

4. Pengujian Hipotesis 4 (H4)

Berdasarkan hasil pengujian hipotesis (uji t) variabel pengembangan karir diperoleh nilai t-hitung sebesar 2,139 dengan nilai signifikansi sebesar 0,037 $(<0,05)$. Tabel distibusi $\mathrm{t}$ dicari pada $\mathrm{a}=5 \%$ dengan derajat bebas $(\mathrm{df})=\mathrm{n}-\mathrm{k}-1=60$ 3-1 = 56, $\mathrm{n}$ adalah jumlah kasus (sampel), $\mathrm{k}$ adalah jumlah variabel independen.

Nilai t-hitung lebih besar dibandingkan nilai t-tabel $(2,139>2.00324)$ dan nilai signifikan lebih kecil dari 0,05, sehingga dapat disimpulkan bahwa variabel pengembangan karir berpengaruh positif terhadap kinerja karyawan KJPP NDR atau H4 diterima, artinya semakin baik pengembangan karirakan meningkatkan kinerja karyawan KJPP NDR.

\section{Pengujian Hipotesis 5 (H5)}

Berdasarkan hasil pengujian hipotesis (uji t) variabel motivasi ektrinsik diperoleh nilai t-hitung sebesar 2,275 dengan nilai signifikansi sebesar 0,027 $(<0,05)$. Tabel distibusi $\mathrm{t}$ dicari pada $\mathrm{a}=5 \%$ dengan derajat bebas $(\mathrm{df})=\mathrm{n}-\mathrm{k}-1=60-3-1=56$, $\mathrm{n}$ adalah jumlah kasus (sampel), $\mathrm{k}$ adalah jumlah variabel independen.

Nilai t-hitung lebih besar dibandingkan nilai t-tabel $(2,275>2.00324)$ dan nilai signifikan lebih kecil dari 0,05, sehingga dapat disimpulkan bahwa variabel motivasi ektrinsik berpengaruh positif terhadap kinerja karyawan KJPP NDR atau H5 diterima, artinya semakin baik motivasi ektrinsik akan meningkatkan kinerja karyawan KJPP NDR. 
6. Pengujian Hipotesis 6 (H6)

Berdasarkan hasil pengujian hipotesis (uji t) variabel motivasi intrinsik diperoleh nilai t-hitung sebesar 4,039 dengan nilai signifikansi sebesar 0,000 (< $0,05)$. Tabel distibusi t dicari pada $\mathrm{a}=5 \%$ dengan derajat bebas $(\mathrm{df})=\mathrm{n}-\mathrm{k}-1=60-3-$ $1=56, \mathrm{n}$ adalah jumlah kasus (sampel), $\mathrm{k}$ adalah jumlah variabel independen.

Nilai t-hitung lebih besar dibandingkan nilai t-tabel $(4,039>2.00324)$ dan nilai signifikan lebih kecil dari 0,05, sehingga dapat disimpulkan bahwa variabel motivasi intrinsik berpengaruh positif terhadap kinerja karyawan KJPP NDR atau H6 diterima, artinya semakin baik motivasi intrinsik akan meningkatkan kinerja karyawan KJPP NDR.

7. Pengujian Hipotesis 7 (H7)

Berdasarkan hasil pengujian hipotesis (uji t) variabel kepuasan kerja diperoleh nilai t-hitung sebesar 2,079 dengan nilai signifikansi sebesar 0,042 $(<0,05)$. Tabel distibusi t dicari pada $\mathrm{a}=5 \%$ dengan derajat bebas $(\mathrm{df})=\mathrm{n}-\mathrm{k}-1=60-3-1=56, \mathrm{n}$ adalah jumlah kasus (sampel), $\mathrm{k}$ adalah jumlah variabel independen.

Nilai t-hitung lebih besar dibandingkan nilai t-tabel $(2,079>2.00324)$ dan nilai signifikan lebih kecil dari 0,05, sehingga dapat disimpulkan bahwa variabel kepuasan kerja berpengaruh positif terhadap kinerja karyawan KJPP NDR atau $\mathbf{H} 7$ diterima, artinya semakin baik kepuasan kerja akan meningkatkan kinerja karyawan KJPP NDR.

\section{Koefisien Determinasi}

Untuk mengetahui persentase pengaruh variabel independen terhadap variabel dependen digunakan koefisien determinan dilihat pada tabel berikut:

\section{Tabel 5}

Koefisien Determinasi

\begin{tabular}{|c|c|}
\hline & $\begin{array}{c}\text { Adjusted R } \\
\text { Square }\end{array}$ \\
\cline { 1 - 1 } Persamaan Regresi I & \multirow{2}{*}{0,374} \\
\hline Motivasi Ekstrinsik & \\
\cline { 1 - 1 } Motivasi Intrinsik & \\
\cline { 1 - 1 } Pengembangan Karir & \multirow{2}{*}{0,531} \\
\cline { 1 - 1 } Persamaan Regresi II & \\
\hline Kepuasan Kerja & \\
\cline { 1 - 2 } Motivasi Ekstrinsik & \\
\cline { 1 - 2 } Motivasi Intrinsik &
\end{tabular}

Sumber : data primer yang diolah 2018

Dari tabel 4.19 di atas menunjukkan dapat dihitung total $\mathrm{R}^{2}$ dengan langkahlangkah sebagai berikut:

1) Menghitung Error term (unsur gangguan/kesalahan penganggu)

$$
\begin{aligned}
\mathrm{e}_{1} & =\sqrt{1-\left(R_{1}\right)^{2}} \\
& =\sqrt{1-(0.374)^{2}} \\
& =\sqrt{0.0860}
\end{aligned}
$$




$$
\text { 2) } \begin{aligned}
& =0.293 \\
& =\sqrt{1-\left(R_{2}\right)^{2}} \\
& =\sqrt{1-(0.531)^{2}} \\
& =\sqrt{0.7180} \\
& =0.847
\end{aligned}
$$

3) Total $R^{2}$

$$
\begin{aligned}
& =1-\left(\mathrm{e}_{1}\right)^{2} \cdot\left(\mathrm{e}_{2}\right)^{2} \\
& =1-(0.293)^{2} \cdot(0.847)^{2} \\
& =1-0,062 \\
& =0,938
\end{aligned}
$$

Dari tabel 4.19 di atas menunjukkan bahwa total $\mathrm{R}^{2}$ adalah 0,938 . Hal ini menunjukkan bahwa 93,8\% variabel kinerja karyawan KJPP NDR dapat dijelaskan oleh pengembangan karir, motivasi ekstrinsik, motivasi intrinsik dan kepuasan kerja, sedangkan sisanya sebesar 6,2\% dijelaskan oleh variabel lain di luar model penelitian.

\section{Analisis Jalur (Path Analysis)}

Untuk menguji pengaruh variabel intervening/mediasi digunakan metode analisis jalur (Path Analysis). Analisis jalur merupakan perluasan dari analisis regresi linear berganda, atau analisis jalur adalah penggunaan analisis regresi untuk menaksir hubungan kausalitas antar variabel (model casual) yang telah ditetapkan sebelumnya berdasarkan teori.

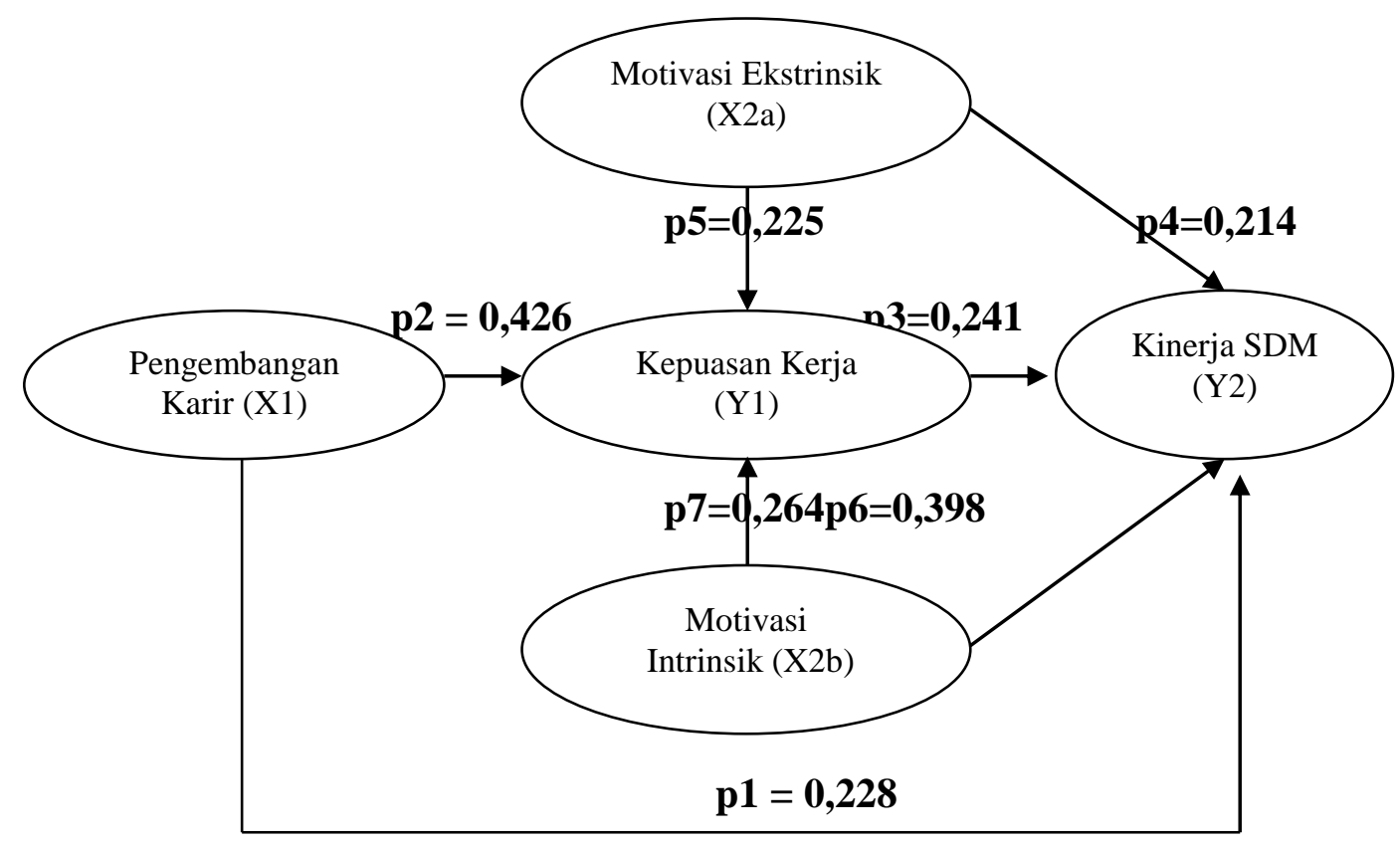

\section{Gambar 1}

\section{Model Analisis Jalur (Path Analysis)}

Berdasarkan gambar di atas diketahui bahwa pengaruh langsung pengembangan karir, motivasi ekstrinsik, dan motivasi intrinsik terhadap kinerja SDM lebih tinggi dibandingkan pengaruh pengembangan karir terhadap kinerja SDM melalui kepuasan kerja. 


\section{Pembahasan}

\section{Pengaruh Pengembangan Karir terhadap Kepuasan Kerja Karyawan KJPP NDR}

Berdasarkan hasil penelitian diketahui bahwapengembangan karir berpengaruh positif dan signifikan terhadap kepuasan kerja yang ditunjukkan dengan taraf signifikansinya $0,000(<0,05)$. Hasil penelitian ini sejalan dengan temuan penelitian Lisdiani (2017) yang menyimpulkan bahwa pengembangan karir berpengaruh signifikan terhadap kepuasan kerja pada Hotel Grasia Semarang. Begitu juga halnya dengan penelitian terdahulu yang dilakukan oleh Ambarwati, dkk (2016) yang menunjukkan bahwa pengembangan karir yang terdiri dari persamaan karir, masalah pengawasan, kesediaan akan kesempatan dan minat karyawan berpengaruh signifikan terhadap kepuasan kerja karyawan di PT. Kusuma Satria Dinasasri Wisatajaya.

Mangkunegara (2007), berpendapat bahwa pengembangan karir adalah aktivitas kepegawaian yang membantu pegawai-pegawai merencanakan karir masa depan mereka di perusahaan agar perusahaan dan pegawai yang bersangkutan dapat mengembangkan diri secara maksimum. Pengembangan karir yang diselenggarakan oleh KJPP NDR merupakan langkah yang seharusnya dapat meningkatkan kepuasan kerja karyawan KJPP NDR.

\section{Pengaruh Motivasi Ektrinsik terhadap Kepuasan Kerja Karyawan KJPP NDR}

Berdasarkan hasil penelitian diketahui bahwamotivasi ekstrinsik berpengaruh positif dan signifikan terhadap kepuasan kerja yang ditunjukkan dengan taraf signifikansinya 0,035 $(<0,05)$. Hasil penelitian ini sejalan dengan teori Herzberg $(1960)$ dalam Tampubolon (2004) yang mengemukakan bahwa ada serangkaian kondisi ekstrinsik, di mana keadaan pekerjaan dan hygieni yang menyebabkan rasa tidak puas di antara para karyawan apabila kondisi ini tidak ada, maka hal ini tidak perlu memotivasi karyawan. Sebaliknya, apabila keadaan pekerjaan dan hygieni cukup baik, keadaan ini dapat membentuk kepuasan bagi karyawan.

Hasil penelitian ini juga sejalan dengan temuan penelitian dari Putra dan Frianto (2016) yang menunjukkan bahwa motivasi ekstrinsik mempunyai pengaruh positif terhadap kepuasan kerja Departemen Sumber Daya Manusia di PT. Semen Gresik (Persero) Tbk. Terpenuhinya motivasi ekstrinsik dalam diri karyawan akan semakin meningkatkan kepuasan kerja KJPP NDR.

\section{Pengaruh Motivasi Intrinsik terhadap Kepuasan Kerja Karyawan KJPP NDR}

Berdasarkan hasil penelitian diketahui bahwamotivasi intrinsik berpengaruh positif dan signifikan terhadap kepuasan kerja yang ditunjukkan dengan taraf signifikansinya $0,018(<0,05)$. Herzberg berpendapat bahwa apabila para manajer ingin memberikan motivasi pada bawahannya, yang perlu ditekankan adalah faktor-faktor yang menimbulkan rasa puas, yaitu dengan mengutamakan faktor-faktor motivasional yang bersifat internal (Noermijati, 2010). Juga seperti yang ditemukan oleh Octaviana (2011), Purnomowati (2006), Brahmasari dan Suprayetno (2008) bahwa motivasi sangat memengaruhi kepuasan kerja dan Noermijati (2008) yang mengemukakan bahwa faktor intrinsik/motivator memengaruhi kepuasan manajer operasional. Motivasi intrinsik melibatkan orang yang melakukan suatu kegiatan karena merasa menarik dan memperoleh kepuasan langsung dari kegiatan itu sendiri. Motivasi ekstrinsik membutuhkan perantara antara aktivitas dan beberapa konsekuensi yang dipisahkan seperti penghargaan nyata, sehingga kepuasan berasal dari konsekuensi ekstrinsik yang menuntun kegiatan. 
Hasil penelitian ini sejalan dengan temuan penelitian dari Muslih (2012) menunjukkan bahwa motivasi intrinsik berpengaruh signifikan terhadap kepuasan kerja. Koefisien yang positif mengindikasikan bahwa motivasi intrinsik memberikan pengaruh yang positif terhadap kepuasan kerja. Yang berarti semakin tinggi motivasi intrinsik pegawai, maka kepuasan kerja pegawai akan semakin tinggi pula. Sebaliknya, semakin rendah motivasi intrinsik pegawai, maka kepuasan kerja juga akan semakin rendah.

\section{Pengaruh Pengembangan Karir terhadap Kinerja Karyawan KJPP NDR}

Berdasarkan hasil penelitian diketahui bahwapengembangan karir berpengaruh positif dan signifikan terhadap kinerja karyawan KJPP NDR yang ditunjukkan dengan taraf signifikansinya 0,037 $(<0,05)$. Mangkunegara (2007), berpendapat bahwa pengembangan karir adalah aktivitas kepegawaian yang membantu pegawai-pegawai merencanakan karir masa depan mereka di perusahaan agar perusahaan dan pegawai yang bersangkutan dapat mengembangkan diri secara maksimum. Pengembangan karir juga dapat didefinisikan sebagai semua usaha pribadi karyawan yang ditujukan untuk melaksanakan rencana karirnya melalui pendidikan, pelatihan, pencarian dan perolehan kerja, serta pengalaman kerja (Panggabean, 2002). Pengembangan karir yang diselenggarakan oleh suatu perusahaan dapat meningkatkan kesediaan karyawan KJPP NDR untuk menunjukkan kinerja yang optimal.

Hasil penelitian ini sejalan dengan penelitian terdahulu yang dilakukan oleh Permatasari (2006) menunjukkan bahwa pengembangan karir karyawan yang ditunjukkan dengan variabel perencanaan karir dan manajemen karir yang baik akan memacu kinerja karyawan. Begitu juga Dewi dan Utama (2016) menyimpulkan hasil penelitiannya bahwa pengembangan karir berpengaruh positif dan signifikan terhadap kinerja karyawan. Hal ini menunjukkan semakin baik pengembangan karir karyawan maka semakin meningkat pula kinerja karyawan.

\section{Pengaruh Motivasi Ektrinsik terhadap Kinerja Karyawan KJPP NDR}

Berdasarkan hasil penelitian diketahui bahwamotivasi ekstrinsik berpengaruh positif dan signifikan terhadap kinerja karyawan KJPP NDR yang ditunjukkan dengan taraf signifikansinya 0,027 $(<0,05)$. Mangkunegara (2007) menyatakan bahwa faktorfaktor yang memengaruhi pencapaian kinerja, salah satunya adalah motivasi. Hasil penelitian ini sejalan dengan temuan penelitian yang dilakukan Purwati (2012) menunjukkan bahwa motivasi kerja berpengaruh terhadap kinerja karyawan. Karyawan yang memiliki motivasi kerja akan bersungguh-sungguh dalam bekerja dan berusaha agar setiap target yang ditetapkan oleh perusahaan tercapai. Yangberarti semakin tinggi motivasi ekstrinsik pegawai,maka kinerja pegawai akan semakin tinggi pula. Sebaliknya,semakin rendah motivasi ekstrinsik pegawai,maka kinerja pegawai juga akan semakin rendah.

\section{Pengaruh Motivasi Intrinsik terhadap Kinerja Karyawan KJPP NDR}

Berdasarkan hasil penelitian diketahui bahwamotivasi intrinsik berpengaruh positif dan signifikan terhadap kinerja karyawan KJPP NDR yang ditunjukkan dengan taraf signifikansinya 0,000 $(<0,05)$. Menurut Herzberg Faktor motivator (intrinsik) memotivasi seseorang untuk berusaha mencapai kepuasan, yang termasuk di dalamnya adalah keberhasilan yang diraih, pengakuan atau penghargaan, pekerjaan itu sendiri, tanggung jawab, dan peluang untuk berkembang (faktor intrinsik). 
Motivasi intrinsik merupakan hal yang sangat penting bagi kehidupan suatu organisasi terutama peningkatan kinerja secara optimal. Sejalan dengan yang ditemukan oleh Mahesa (2010), Purnomowati (2006), Widyastuti (2004), Octaviana (2011), dan Nugraheni (2003) bahwa motivasi ekstrinsik mempunyai pengaruh yang signifikan terhadap kinerja pegawai. Penelitian terdahulu yang dilakukan Prahiawan dan Simbolon (2014) menunjukkan bahwa motivasi intrinsik mempunyai pengaruh yang signifikan terhadap kinerja karyawan pada PT. Intimas Lestari Nusantara. Adanya motivasi intrinsik pada karyawan KJPP NDR akan semakin meningkatkan kinerja karyawan.

\section{Pengaruh Kepuasan Kerja terhadap Kinerja Karyawan di KJPP NDR}

Berdasarkan hasil penelitian diketahui bahwakepuasan kerja berpengaruh positif dan signifikan terhadap kinerja karyawan KJPP NDR yang ditunjukkan dengan taraf signifikansinya $0,042(<0,05)$. Salah satu langkah penting yang dapat dilakukan oleh perusahaan guna mencapai kinerja yang optimal adalah meningkatkan kepuasan kerja karyawan. Hasil penelitian ini sejalan dengan penelitian terdahulu yang dilakukan oleh Hasil penelitian yang dilakukan Mardiana, dkk (2014: 127) menunjukkan bahwa terdapat hubungan antara kepuasan kerja dengan turnover intention. Semakin tinggi tingkat kepuasan seseorang maka akan membuat orang tersebut semakin tidak ingin meninggalkan pekerjaan atau resign. Lebih lanjut penelitian Baroroh (2016) menunjukkan bahwa kepuasan kerja berpengaruh positif terhadap kinerja. Terpenuhinya kepuasan kerja pada karyawan KJPP NDR akan semakin meningkatkan rasa nyaman karyawan dalam bekerja, sehingga dengan sendirinya karyawan akan menunjukkan kinerja yang maksimal.

\section{PENUTUP}

\section{Simpulan}

Berdasarkan hasil penelitian maka dapat diambil beberapa simpulan sebagai berikut:

1. Pengembangan karir mempengaruhi kepuasan kerja karyawan KJPP NDR.Hal ini berarti bahwa semakin baik pengembangan karir, maka akan semakin tinggi pula kepuasan kerja karyawan KJPP NDR. Oleh karena itu, untuk meningkatkan kepuasan kerja karyawan karyawan KJPP NDR, perlu pengembangan karir yang jelas bagi karyawan, Indikator tertinggi dari pengembangan karir adalah perusahaan dianggap telah menyebarkan informasi mengenai karir kepada karyawan KJPP NDR.

2. Motivasi ektrinsik mempengaruhi kepuasan kerja karyawan KJPP NDR.Hal ini berarti bahwa semakin tinggimotivasi ektrinsik, maka akan semakin tinggi pula kepuasan kerja karyawan KJPP NDR, indikator tertinggi dari motivasi ektrinsik adalah peraturan perusahaan yang dianggap sesuai dengan diri karyawan KJPP NDR.

3. Motivasi intrinsik mempengaruhi kepuasan kerja karyawan KJPP NDR. Hal ini berarti bahwa semakin tinggi motivasi intrinsik, maka akan semakin tinggi pula kepuasan kerja karyawan KJPP NDR. Indikator tertinggi dari motivasi intrinsik, adalah dorongan untuk mencapai keberhasilan dalam menyelesaiakan pekerjaan.

4. Terdapat pengaruh positif pengembangan karir terhadap kinerja karyawan KJPP NDR. Hal ini berarti bahwa semakin baikpengembangan karir, maka akan semakin tinggi pula kinerja karyawan KJPP NDR.Pengaruh langsung pengembangan karir terhadap kinerja karyawan KJPP NDR lebih besar pengaruhnya dibanding pengaruh antara pengembangan karir dan kepuasan kerja sebagai variabel intervening untuk meningkatkan kinerja karyawan KJPP NDR. 
5. Terdapat pengaruh positif motivasi eksrinsik terhadap kinerja karyawan KJPP NDR. Hal ini berarti bahwa semakin tinggimotivasi eksrinsik, maka akan semakin tinggi pula kinerja karyawan KJPP NDR. Pengaruh langsung motivasi eksrinsik terhadap kinerja karyawan KJPP NDR lebih besar pengaruhnya dibanding pengaruh antara motivasi eksrinsik dan kepuasan kerja sebagai variabel intervening untuk meningkatkan kinerja karyawan KJPP NDR.

6. Terdapat pengaruh positif motivasi intrinsik terhadap kinerja karyawan KJPP NDR. Hal ini berarti bahwa semakin tinggi motivasi intrinsik, maka akan semakin tinggi pula kinerja karyawan KJPP NDR.Pengaruh langsung motivasi intrinsik terhadap kinerja karyawan KJPP NDR lebih besar pengaruhnya dibanding pengaruh antara motivasi intrinsik dan kepuasan kerja sebagai variabel intervening untuk meningkatkan kinerja karyawan KJPP NDR.

7. Terdapat pengaruh positif kepuasan kerja terhadap kinerja karyawan KJPP NDR. Hal ini berarti bahwa semakin tinggi kepuasan kerja, maka akan semakin tinggi pula kinerja karyawan KJPP NDR.

\section{Implikasi Manajerial}

Berdasarkan temuan penelitian, maka ada beberapa implikasi kebijakan sesuai dengan prioritas yang dapat diberikan sebagai masukan bagi organisasi dalam hal ini KJPP Jimmy Prasetyo \& Rekan, antara lain:

1. Berdasarkan hasil analisis jalur direct effect, maka terlihat bahwa pengembangan karir berpengaruh langsung terhadap kinerja karyawan KJPP NDR. Untuk dapat meningkatkan kinerja karyawan KJPP NDR, maka sebaiknya jajaran pimpinan pada KJPP NDR terlebih dahulu meningkatkan pengembangan karir. Pengembangan karir dapat ditingkatkan dengan meningkatkan peluang pengembangan karir bagi karyawan ataupun menunjukkan kejelasan rencana karir jangka panjang dan jangka pendek, sehingga karyawan KJPP NDR semakin bersedia menunjukkan kinerja yang maksimal.

2. Berdasarkan hasil analisis jalur direct effect dan indirect effect, maka terlihat bahwa pengembangan karir berpengaruh langsung dan tidak langsung terhadap kinerja karyawan KJPP NDR. Untuk dapat meningkatkan kinerja karyawan KJPP NDR, maka sebaiknya jajaran pimpinan pada KJPP NDR selain meningkatkan pengembangan karir juga harus memperhatikan kepuasan kerja karyawan.Kepuasan kerja dapat ditingkatkan seiring dengan meningkatkan pengembangan karir dalam perusahaan, sehingga kinerja karyawan KJPP NDR juga akan semakin meningkat. Selain kepuasan terhadap pengembangan karir yang ada perusahaan, adanya gaji ataupun rekan kerja yang mendukung pelaksanaan pekerjaan juga dapat meningkatkan kepuasan kerja, yang nantinya dapat semakin meningkatkan kinerja karyawan KJPP NDR.

3. Berdasarkan hasil analisis jalur direct effect, maka terlihat bahwa motivasi ekstrinsik berpengaruh langsung terhadap kinerja karyawan KJPP NDR. Untuk dapat meningkatkan kinerja karyawan KJPP NDR, maka sebaiknya jajaran pimpinan pada KJPP NDR terlebih dahulu meningkatkan motivasi ekstrinsik dari karyawan KJPP NDR. Motivasi ekstrinsik dapat ditingkatkan dengan meningkatkan hubungan interpersonal yang dekat dengan karyawan, sehingga karyawan dapat merasakan kenyamanan dalam bekerja dan bersedia meningkatkan kinerjanya.

4. Berdasarkan hasil analisis jalur direct effect dan indirect effect, maka terlihat bahwa motivasi ekstrinsik berpengaruh langsung dan tidak langsung terhadap 
kinerjakaryawan KJPP NDR.Untuk dapat meningkatkan kinerja karyawan KJPP NDR, maka sebaiknya jajaran pimpinan pada KJPP NDR selain meningkatkan motivasi ekstrinsik juga harus memperhatikan kepuasan kerja karyawan. Peningkatan motivasi ekstrinsik dari karyawan, yaitu melalui lingkungan kerja yang mendukung pelaksanaan pekerjaan akan mendorong munculnya kepuasan dalam diri karyawan KJPP NDR, sehingga karyawan KJPP NDR semakin menunjukkan kinerja yang meningkat.

5. Berdasarkan hasil analisis jalur direct effect, maka terlihat bahwa motivasi intrinsik berpengaruhlangsung terhadap kinerja karyawan KJPP NDR. Untuk dapat meningkatkan kinerja karyawan KJPP NDR, maka sebaiknya jajaran pimpinan pada KJPP NDR terlebih dahulu meningkatkan motivasi intrinsik dari karyawan KJPP NDR. Motivasi intrinsik dapat ditingkatkan dengan meningkatkan meningkatkan penghargaan atas prestasi kerja yang dicapai karyawan, seperti halnya pemberian reward ketika karyawan berhasil mencapai target kerja.

6. Berdasarkan hasil analisis jalur direct effect dan indirect effect, maka terlihat bahwa motivasi intrinsik berpengaruh langsung dan tidak langsung terhadap kinerja karyawan KJPP NDR.Untuk dapat meningkatkan kinerja karyawan KJPP NDR, maka sebaiknya jajaran pimpinan pada KJPP NDR selain meningkatkan motivasi intrinsik juga harus memperhatikan kepuasan kerja karyawan. Peningkatan motivasi intrinsik dari karyawan, yaitu melalui pemberian balas jasa yang sesuai dengan jarih payah yang diberikan karyawan terhadap perusahaan akan mendorong munculnya kepuasan dalam diri karyawan KJPP NDR, sehingga karyawan KJPP NDR semakin menunjukkan kinerja yang meningkat.

7. Berdasarkan hasil analisis jalur direct effect, maka terlihat bahwa kepuasan kerja berpengaruh langsung terhadap kinerja karyawan KJPP NDR. Untuk dapat meningkatkan kinerja karyawan KJPP NDR, maka sebaiknya jajaran pimpinan pada KJPP NDR meningkatkan kepuasan kerja dari karyawan KJPP NDR. Kepuasan kerja dapat ditingkatkan dengan hubungan dekat yang terjalin diantara masing-masing karyawan, sehingga dapat saling memberikan semangat ketika karyawan merasa tertekan dengan target pekerjaan.

\section{Keterbatasan dalam Penelitian}

Terdapat beberapa keterbatasan dalam penelitian ini, yaitu sebagai berikut:

1. Model yang dibangun dari variabel yang digunakan dalam penelitian ini belum sempurna, karena kemampuan menjelaskan dari keseluruhan variabel dalam model, tidak mencapai Adjusted RSquare sebesar 1 atau 100\%, seperti pengembangan karir, motivasi ekstrinsik, motivasi intrinsik, dan kepuasan kerja menjelaskan sebesar $53,1 \%$ dari variabel kinerja SDM.Sedangkan sisanya sebesar $(100-53,1 \%)$ yaitu sebesar 46,9\% dijelaskan oleh variabel lain di luar model penelitian.

2. Variabel yang digunakan dalam penelitian ini hanya pengembangan karir, motivasi ekstrinsik, motivasi intrinsik, dan kepuasan kerja terhadap kinerja SDM. Kemungkinan masih ada variabel lain yang juga turut berpengaruh terhadap kinerja karyawan KJPP NDR.

\section{DAFTAR PUSTAKA}

Ambarwati, F. A. D., Kustiani, L., dan Mudzakkir, M. F. 2017. Pengaruh Pengembangan Karir terhadap Kepuasan Kerja Karyawan di PT. Kusuma Satria Dinasasri Wisatajaya Batu. Jurnal Riset Mahasiswa Manajemen (JRMM). Vol. 3. No. 1. 
Baroroh, A. 2016. Pengaruh Pengembangan Karir dan Motivasi terhadap Kinerja dengan Kepuasan Kerja sebagai Variabel Intervening (Studi Kasus pada Politeknik Ilmu Pelayaran Semarang). Jurnal Ilmu Manajemen. Vol. 1. No. 2: 6580.

Brahmasari, I.A., dan Suprayetno, A. 2008. Pengaruh Motivasi Kerja, Kepemimpinan dan Budaya Organisasi terhadap Kepuasan Kerja Karyawan serta Dampaknya pada Kinerja Perusahaan. Tesis. Universitas 17 Agustus Surabaya.

Dewi, N.L.P.A.A., dan Utama, I.W.M. 2016. Pengaruh Pengembangan Karir terhadap Kinerja Karyawan Melalui Mediasi Motivasi Kerja pada Karya Mas Art Gallery. E-Jurnal Manajemen Unud. Vol. 5, No.9: 5494-5523.

Guritno, Bambang dan Waridin. 2005. Pengaruh Persepsi Karyawan Mengenai Perilaku Kepemimpinan, Kepuasan Kerja dan Motivasi terhadap Kinerja. JRBI. Vol 1. No 1. Hal: 63-74.

Harahap, Vivi Amanah., dan Hidayat, Wahyu. (2017). Pengaruh Motivasi dan Lingkungan Kerja terhadap Kinerja Melalui Kepuasan Kerja Sebagai Variabel Intervening (Studi pada PT. Taspen (Persero) Kantor Cabang Utama Semarang). Jurnal Ilmu Manajemen. Vol. 1. No. 2: 1-8.

Lisdiani, V. 2017. Pengaruh Pengembangan Karir terhadap kepuasan Kerja Karyawan di PT. Kusuma Satria Dinasasri Wisatajaya Batu. Diponegoro Journal of Social and Political Science. Tahun 2017, Hal 1-8.

Lusri, Lidia dan Siagian, Hotlan. 2017. Pengaruh Motivasi Kerja terhadap Kinerja Karyawan melalui Kepuasan Kerja sebagai Variabel Mediasi pada Karyawan PT. Borwita Citra Prima Surabaya. Agora. Vol. 5. No. 1: 1-8.

Mahesa, D. 2010. Analisis Pengaruh Motivasi dan Kepuasan Kerja terhadap Kinerja Karyawan Dengan Lama Kerja Sebagai Variabel Moderating. Skripsi. Semarang: Fakultas Ekonomi Universitas Diponegoro.

Mangkunegara, A.A.A.P. 2007. Evaluasi Kinerja SDM. Bandung: PT. Refika Aditama.

Mangkunegara, Anwar. P. 2013. Manajemen Sumber Daya Manusia dan Perusahaan. Bandung : Remaja Rosdakarya.

Massie, Renaldy Bernhard Tewal, Greis Sendow. 2015. Pengaruh Perencanaan Karir, Pelatihan dan Pengembangan Karir terhadap Kinerja Pegawai pada Museum Negeri Provinsi Sulawesi Utara.

Muslih, B. 2012. Analisis Pengaruh Motivasi terhadap Kepuasan Kerja dan Kinerja Pegawai di PT Sang Hyang Seri (Persero) Regional III Malang. Jurnal Aplikasi Manajemen. Vol. 10. No. 4: 799-810. 
Ningsih, I. M. 2012. Hubungan antara Komunikasi Interpersonal dan Pengembangan Karir dengan Kepuasan Kerja. Empathy. Vol.I No.1: 260-272.

Noermijati, 2010. Kajian Deskriptif tentang Kondisi Faktor Intrinsik dan Ekstrinsik serta Kepuasan Kerja Manajer Menengah-Bawah. Jurnal Aplikasi Manajemen. Vol. 8 No. 1. Malang: Penerbit Percetakan (UM Press).

Nugraheni, D.A. 2003. Pengaruh Motivasi Ekstrinsik dan Motivasi Intrinsik terhadap Kinerja Paramedis Keperawatan (Studi Pada RSUD Gambiran Kediri). Tesis. Pascasarjana Universitas Brawijaya.

Octaviana, N. 2011. Pengaruh Budaya Organisasi terhadap Motivasi dan Kepuasan Kerja serta Kinerja Karyawan. Skripsi. Yogyakarta: Fakultas Ekonomi UPN Veteran.

Panggabean, M. S. 2002. Manajemen Sumber Daya Manusia, Ghalia Indonesia, Bogor.

Permatasari, Ita Rifiani. 2006. Pengaruh Pengembangan Karir terhadap kinerja Karyawan (Studi Kasus di PT.Telkom Malang). Modernisasi. Volume 2, Nomor 3: $177-191$.

Prahiawan, Wawan., dan Simbolon, Nopiyana. 2014. Pengaruh Motivasi Intrinsik dan Lingkungan Kerja terhadap Kinerja Karyawan pada PT Intimas Lestari Nusantara. Jurnal Ekonomi. Volume 5 Nomor 1: 35-41.

Putra, A. K., dan Frianto, A. 2013. Pengaruh Motivasi Intrinsik dan Motivasi Ekstrinsik terhadap Kepuasan Kerja. Jurnal Ilmu Manajemen. Volume 1 Nomor 1: 377-387.

Sutrisno, Edi. 2009. Manajemen Sumber Daya Manusia. Jakarta: Prenada Media Group.

Suwatno dan Priansa, D. 2011. Manajemen Sumber Daya Manusia, Dalam. Organisasi Publik dan Bisnis. Bandung: Alfabeta.

Tampubolon. 2004. Manajemen Operasional. Edisi Pertama. Jakarta: PT.Gramedia Pustaka Utama.

Torang, S. 2013. Organisasi dan Manajemen: Perilaku, Struktur, Budaya dan Perubahan Organisasi. Bandung: Alfabeta.

Wibowo. 2013. Perilaku dalam Organisasi. Jakarta: Rajawali Press.

Widyastuti, Endang, N. 2004. Analisis Pengaruh Iklim Organisasi dan Motivasi terhadap Kinerja Pegawai Melalui Variabel Intervening Kepuasan Kerja. Tesis. Semarang: Magister Manajemen Universitas Diponegoro.

Wijono, S. 2012. Psikologi Industri dan Organisasi: Dalam Suatu Bidang Gerak Psikologi Sumber Daya Manusia. Jakarta: Kencana Prenada Media Group. 